University of Warwick institutional repository: http://go.warwick.ac.uk/wrap This paper is made available online in accordance with publisher policies. Please scroll down to view the document itself. Please refer to the repository record for this item and our policy information available from the repository home page for further information.

To see the final version of this paper please visit the publisher's website. Access to the published version may require a subscription.

Author(s): Mark Webber, Stuart Croft, Jolyon Howorth, Terry Terriff and Elke Krahmann

Article Title: The governance of European security

Year of publication: 2004

Link to published version:

http://dx.doi.org/10.1017/S0260210504005807

Publisher statement: None 


\title{
The governance of European security
}

\author{
MARK WEBBER, STUART CROFT, JOLYON HOWORTH, \\ TERRY TERRIFF AND ELKE KRAHMANN ${ }^{1}$
}

\begin{abstract}
This article seeks to develop a concept of 'security governance' in the context of post-Cold War Europe. The validity of a governance approach lies in its ability to locate some of the distinctive ways in which European security has been coordinated, managed and regulated. Based on an examination of the way governance is utilised in other political fields of political analysis, the article identifies the concept of security governance as involving the coordinated management and regulation of issues by multiple and separate authorities, the interventions of both public and private actors (depending upon the issue), formal and informal arrangements, in turn structured by discourse and norms, and purposefully directed toward particular policy outcomes. Three issues are examined to demonstrate the utility of the concept of security governance for understanding security in post-Cold War Europe: the transformation of NATO, the Europeanisation of security accomplished through EU-led initiatives and, finally, the resultant dynamic relationship between forms of exclusion and inclusion in governance.
\end{abstract}

\section{Introduction}

Thinking about European security has been shaped by a series of different ideas and concepts over the past quarter of a century: an architecture, regime, community. However, it has not been subjected to an account through the lens of governance. Given the application of the concept to a range of other thematic areas, this is rather surprising. This article seeks to explore 'security governance' in the context of post-Cold War Europe. The validity of a governance approach lies in its ability to locate some of the distinctive ways in which European security has been coordinated, managed and regulated. Three issues are chosen to illustrate this: the transformation of NATO, the Europeanisation of security accomplished through EU-led initiatives and, finally, the resultant dynamic relationship between forms of exclusion and inclusion in governance.

The timing of research into security governance in Europe might be seen to be rather challenging. From a series of arguments about the nature and balance of institutional responsibilities, to debates over the role of institutions in the global 'war on terror', to the seeming marginalisation of those institutions in the war in

\footnotetext{
1 The authors acknowledge research support provided by the Economic and Social Research Council (ESRC) for the project on 'Security Governance in the New Europe' (Project Grant L213252008), part of the ESRC 'One Europe or Several?' programme. The authors also thank all those people who gave time to discuss this article and the editors and the three anonymous referees of this Journal for their constructive comments.
} 
Iraq, it has been difference that has seemingly been the hallmark of European security interaction. Indeed, this might raise a question about why think in terms of governance now; why at all? Other frameworks are viable, networks perhaps most obviously. Governance is, however, an obvious choice, not least because in a sense, it is the concept that policymakers have sought to develop. Governance also encompasses many of the central themes of European security: the importance of ideas, of institutions and both formal and informal structures, of multiple actors purposefully motivated. Security governance might also be able to emphasise key strengths of other approaches: being based on both shared epistemologies (as with epistemic communities) and on shared ontologies (as with sociological institutionalism).

\section{Governance and security governance}

The concept of governance has, of course, been widely applied in Political Science. Moreover, it has been used in a variety of ways in the International Relations (IR) literature. That there is a security dimension to governance is thus not conceptually untoward. For the purposes of this article, as applied to European security, governance involves the coordinated management and regulation of issues by multiple and separate authorities, the interventions of both public and private actors (depending upon the issue), formal and informal arrangements, in turn structured by discourse and norms, and purposefully directed toward particular policy outcomes.

That said, the term has been victim to use and abuse. 'Governance' has become one of those terms that is utilised by so many, in so many different fashions, that it begins to defy clear definition. The notion of 'global governance' has become familiar in the vocabulary of IR and it is now accompanied by sundry, more specific applications: environmental governance, trade governance, international monetary governance and so on. The term has also become commonplace amongst international organisations. The European Commission has adopted a series of measures expressly aimed at improving 'European governance'; the IMF and the World Bank have, since the 1980s, been concerned with promoting 'good governance' in their lending policies; and the UN through its Department of Political Affairs and the UN Development Programme has a specific commitment to the promotion of democratisation and governance. These examples are not meant to suggest that the term has been knowingly misapplied, only that it has been used so often and in so many different ways that its analytical precision has been blunted. Rod Rhodes has observed that the 'problems of definition [... are] acute' and at least six separate and broad uses of the term governance can be identified. ${ }^{2}$ In a similar vein, George Pagoulatos has noted, "[t]he term "governance" has been extensively used in the literature and begs for clarification. All too often its generic usage has tended to become conflated with the substantive one. It is often unclear whether one is referring to types of governance or to a governance type [...].'

2 Rod Rhodes, 'The New Governance: Governing Without Government', Political Studies, $44: 4$ (1996), p. 653.

3 George Pagoulatos, 'European Banking: Five Modes of Governance', West European Politics, 22:1 (1999), p. 68. 
Such analytical eclecticism might be seen as an advantage insofar as it allows of the use of a single and thus comparable concept across a range of issue areas or activities in international life. Indeed, there exists a distinct body of work both within IR and Political Science more broadly which has worked with governance in a manner that has been intended to illustrate, to understand and to explain distinct forms of political interaction. This body of work is, of course, familiar to those working on the EU, or domestically with regard to local government and the management of social, welfare, economic and other spheres of public policy. ${ }^{4}$ Governance by this view has specific meanings and particular applications. In what follows, the particular relevance of the concept to security will be examined.

One of the key propositions of the governance literature - that governance is a phenomenon that is distinct from government - is of course highly significant. Government traditionally understood is suggestive of centralised authority, vertical and hierarchical forms of regulation, and an ability to impose policy preferences, by coercive means if necessary. Governance, by contrast, is concerned with understanding how the regulation of societies has been supplemented by the roles of political actors other than government as such. ${ }^{5}$ In the international realm, the distinction is of particular relevance given the absence of an 'overarching governmental authority' yet the existence of 'a modicum of order [and] of routinised arrangements' that sustain 'global life'. 6 This is close to what Bob Jessop has referred to in a different context as the 'heterarchy of self-organisation' 7 and assumes the existence of multiple centres of power and thus a multiplicity of combined and coordinated actions taken in response to the increasingly complex challenges of governing in a globalising world. ${ }^{8}$

The actors involved in this process of self-organisation are numerous. As the Commission on Global Governance has noted, '[g]overnance is the sum of the many ways individuals and institutions, public and private, manage their common affairs'. Such a formulation suggests a move away from state-centrism and, indeed, governance perspectives are characterised by an attention to 'institutions, corporate interests, civil society, and transnational organisations' as well as the state and government. ${ }^{10}$ Indeed, even in the security sphere - an area traditionally reserved for the state - non-state actors have become increasingly significant in the implement-

4 Beate Kohler-Koch and Rainer Eising (eds.), The Transformation of Governance within the European Union (London: Routledge, 1999); Rhodes, 'The New Governance', pp. 652-67.

5 Jon Pierre, 'Introduction: Understanding Governance', in Jon Pierre (ed.), Debating Governance (Oxford: Oxford University Press, 2000), pp. 3-4.

6 James Rosenau, 'Governance, Order and Change in World Politics', in James Rosenau and Ernst-Otto Czempiel (eds.), Governance without Government: Order and Change in World Politics (Cambridge: Cambridge University Press, 1992), p. 7.

7 Bob Jessop, 'The Changing Governance of Welfare: Recent Trends in its Primary Functions, Scale and Modes of Coordination', Social Policy and Administration, 33:4 (1999), p. 351. Heterarchy refers to forms of coordinated behaviour that are distinct from modes such as anarchy (for example, the free market) or hierarchy (vertical coordination by the state/government).

8 James Rosenau, 'Change, Complexity, and Governance in Globalising Space', in Pierre (ed.), Debating Governance, p. 172; and Jon Pierre and B. Guy Peters, Governance, Politics and the State (Houndmills, Basingstoke: Macmillan, 2000), pp. 59-60.

9 Commission on Global Governance, Our Global Neighbourhood: The Report of the Commission on Global Governance (Oxford: Oxford University Press, 1995), p. 2.

10 Jon Pierre, 'Introduction: Understanding Governance', in Pierre (ed.), Debating Governance, p. 4. 
ation and monitoring of security policies. This is a process that accords with a broadened meaning of security. To long-established actors in the defence industry have been added an increased number of charities, environmental organisations, human rights watchdogs, medical organisations and think-tanks. Further, the privatisation of armaments industries in Western Europe from the 1990s and the professionalisation of armed forces have led to a shift from national autonomy in security affairs to new forms of public-private partnership. ${ }^{11}$ In some circumstances, governments are also finding it more efficient to hire private firms for international tasks rather than attempting to muster the relevant resources themselves. ${ }^{12}$

These processes notwithstanding, in the sphere of security governance, states and the international organisations through which they act remain the primary actors. This is an empirical, rather than a theoretical point. The state may increasingly be pooling its sovereignty and decision-making capacity with other states in the face of transnational and globalising influence. But in European security issues (and indeed, arguably in many wider security issues) the state has remained resilient (albeit not unaltered) in the face of these influences. ${ }^{13}$ The United States has successfully converted a transnational threat (al Qaeda) into a state one, thus legitimising the use of force to produce regime change in Afghanistan and Iraq. This may not be the most appropriate response or understanding of the nature of new threats. But it has empirically reinforced the emphasis on the state. Individuals, societies and other referents of security may be more important theoretically or normatively. ${ }^{14}$ However, in regard to contemporary security issues (especially in Europe), states remain dominant actors. ${ }^{15}$ States are still the agents through which the structures of governance are instituted and financed, and the agents through which the efforts of these structures are largely realised. ${ }^{16}$

This concentration on states notwithstanding, governance is not state-centric in the neorealist sense. Indeed, both institutionalist and regime analyses are compatible with a governance perspective. Governance involves 'formal institutions and regimes $[\ldots]$ as well as informal arrangements that people and institutions either have agreed to or perceive to be in their best interest." ${ }^{17}$ How this interest is generated is of some significance. Much institutionalist thought now recognises that

11 See, for instance, the part-privatisation of the British Defence Evaluation and Research Agency in July 2000.

12 The US government, for example, hired Military Professional Resources Incorporated (MPRI) a private company based in Alexandria, Virginia, for the training of the newly established Croat army in 1994. On the role of private actors in military security see T. K. Adams, 'The New Mercenaries and the Privatisation of Conflict', Parameters, 29:2 (1999), pp. 103-116; and C. Spearin, 'Private Security Companies and Humanitarians: A Corporate Solution to Securing Humanitarian Spaces', International Peacekeeping, 8:1 (2001), pp. 20-43.

13 Pierre and Peters, Governance, Politics and the State, ch. 8.

14 Steve Smith, 'The Increasing Insecurity of Security Studies: Conceptualising Security in the Last Twenty Years', in Stuart Croft and Terry Terriff (eds.), Critical Reflections on Security and Change (London: Frank Cass, 2000), p. 84.

15 Barry Buzan and Richard Little, International Systems in World History: Remaking the Study of International Relations (Oxford: Oxford University Press, 2000), p.101.

16 B. Guy Peters, 'Globalisation, Institutions and Governance' (European University Institute, Jean Monnet Chair Paper, RSC no.98/51, 1998), <http://www.iue.it/EF/Peters.htm> [5/9/02]; and Pierre and Peters, Governance, Politics and the State, esp. pp. 193-209.

17 Commission on Global Governance, Our Global Neighbourhood, p. 2. 
the 'rational prudence' of actors does not fully explain their cooperative interactions ${ }^{18}$ and that underlying beliefs and ideas are also important in explaining action. ${ }^{19}$

An important step, then, is to stress that ideas or norms underpin governance. As James Rosenau has argued, '[g]overnance is [...] a system of rule that is as dependent on inter-subjective meanings as on formally sanctioned constitutions [...]'. ${ }^{20}$ This is a logical consequence of the fact that governance is not dependent upon vertical authority. In the absence of compulsion, collective action, while facilitated by institutional mechanisms, remains dependent in the first instance upon a willingness to act and a consistency of views on a desirable end state. Similarly, formal interaction within institutionalised settings is predicated upon what Friis and Murphy have dubbed 'soft governance' - 'the development of norms and values which condition [...] actions'. ${ }^{21}$ Of principal significance in this regard is the norm of legitimacy 'the belief by an actor that a rule or institution ought to be obeyed', a crucial consideration because it confers authority upon governance structures. ${ }^{22}$

All of this, in turn, suggests that ideas matter in international politics ${ }^{23}$ and this is particularly so in Europe where the ideational terrain has changed significantly since the end of the Cold War. Ideas, however, do not 'float freely'. ${ }^{24}$ They are embedded in material structures and thus reflect and reproduce relationships of power. ${ }^{25}$ These structures include states and international institutions broadly defined. The US, for instance, represents a particularly powerful and hegemonic vehicle for the projection of certain ideas of democracy, markets and institutional commitment. International organisations such as NATO, the EU and the Council of Europe, meanwhile, are receptacles of congruent ideas, and interpret and project them as appropriate norms of international behaviour. It is these ideas or norms that facilitate the development of a dominant model of governance in Europe and suggest an ability of dominant international organisations to act as socialising agents both for their member states and for aspirants and non-members within the region. ${ }^{26}$ But the fact that ideas do

18 Andrew Hurrell, 'International Society and the Study of Regimes. A Reflective Approach', in Volker Rittberger (ed.), Regime Theory and International Relations (Oxford: Clarendon Press, 1995), pp. 49-72.

19 Judith Goldstein and Robert Keohane (eds.), Ideas and Foreign Policy: Beliefs, Institutions and Political Change (Ithaca, NY and London: Cornell University Press, 1993).

20 Rosenau, 'Governance, Order and Change', p. 5.

21 Lykke Friis and Anna Murphy, 'The European Union and Central and Eastern Europe: Governance and Boundaries', Journal of Common Market Studies, 37:2 (1999), p. 214.

22 Ian Hurd, 'Legitimacy and Authority in International Politics', International Organisation, 53:2 (1999), p. 381.

23 As already noted this is part of institutionalist thinking. It is most obviously apparent, however, in social constructivism. See especially, Alexander Wendt, Social Theory of International Politics (Cambridge: Cambridge University Press, 2000).

24 Here we borrow from Thomas Risse-Kappen, 'Ideas Do Not Float Freely: Transnational Coalitions, Domestic Structures, and the End of the Cold War', International Organization, 48:2 (1994) .

25 Ted Hopf, 'The Promise of Constructivism in International Relations Theory', International Security, 23:1 (1998), pp. 177-80; and Andreas Bieler, 'Questioning Cognitivism and Constructivism in IR Theory: Reflections on the Material Structure of Ideas', Politics, 21:2 (2001), pp. 93-100.

26 Frank Schimmelfennig, 'International Socialisation in the New Europe: Rational Action in an Institutional Environment', European Journal of International Relations, 6:1 (2000), pp. 109-39. For the general proposition see Martha Finnemore, National Interests in International Society (Ithaca, NY and London: Cornell University Press, 1996). 
not 'float freely' means that there is a competition between actors on ideas to achieve particular purposes in the security field and this imparts a dynamism to security governance. Within the dominant Westernistic community of norms there has been a debate about the merits of Euro-Atlantic approaches to security (encapsulated within NATO) and Europeanist approaches (encapsulated within the EU). These debates have been made more stark by the policy fall-out of September 11th 2001 and the associated 'war on terrorism', but they have a lineage that extends back through the 1990s and into the period of the Cold War itself. More broadly, while the post-Cold War period has not seen a competition of ideas as stark as during the Cold War, the degree of acceptance of the dominant set of norms has been less than total in some cases. Security governance is, however, rooted in this discourse; the discourse concerns alternative modes of governance, not the subversion of security governance itself.

Finally, the concept of security governance is underpinned by purposefulness. James Rosenau has defined governance 'as systems of rule, as the purposive activities of any collectivity that sustain mechanisms designed to insure its safety, prosperity, coherence, stability, and continuance'. He continues by suggesting that 'governance is about the maintenance of collective order, the achievement of collective goals, and the collective processes of rule through which order and goals are sought' ${ }^{27}$ Purpose here can be understood as the outcome of both structure and process. In structural terms, governance involves institutions (as discussed above) and these entrench particular forms of behaviour among their participants by prescribing rules of entry, norms of interaction and constraints on behaviour. ${ }^{28}$ In terms of process, governance is concerned with policy outcomes and the manner in which actors interact to define and achieve these. In this respect there is an assumption that 'the inclusion and influence of different actors could well change over time and across sectors'. ${ }^{29}$ This suggests that the objectives of systems of governance reflect an aggregate of preferences among actors. These preferences will often be similar but on occasion they may be contested, the consequence of the competition of ideas noted above. Specified policy outcomes can, of course, be obtained, for there are circumstances in which agreed preferences can be manufactured and implemented. However, it may be the case that these meet the objectives of a majority but not necessarily of all actors. ${ }^{30}$

To recap, then, 'security governance' as set out above, comprises five features: heterarchy; the interaction of a large number of actors, both public and private; intitutionalisation that is both formal and informal; relations between actors that are ideational in character, structured by norms and understandings as much as by formal regulations; and, finally, collective purpose. To consider security governance in greater detail, three examples will be taken: the transformation of NATO, 'Europeanisation' and the interaction between inclusion and exclusion.

27 Rosenau, 'Change, Complexity and Governance', pp. 171, 175.

28 Robert Keohane, 'International Institutions: Two Approaches', International Studies Quarterly, 32 (1988), p. 384.

29 Pierre and Peters, Governance, Politics and the State, p. 22.

30 Marie-Claude Smouts, 'The Proper Use of Governance in International Relations', International Social Science Journal, 155 (1998), p. 87. 


\section{NATO's transformation}

The key arena in which security governance in Europe has arguably emerged is within and between international organisations. The principal actor in this regard is NATO and it has obtained a pre-eminent position through a number of processes. ${ }^{31}$

NATO has retained and, indeed, invoked its formal collective defence function. With the passing of the Cold War, collective defence may no longer occupy centre stage in defining the Alliance's purposes. However, obtaining protection under Article $\mathrm{V}$ of the Washington Treaty retains a powerful allure and, whatever the mix of motives, has been one factor in the demand for membership which has propelled enlargement of the organisation in the 1990s and 2000s. In the European setting there is no organisation that offers an equivalent guarantee. The collective defence guarantee of the Western European Union (WEU) still lives on in a state of suspended animation following the formal absorption of that organisation within the EU, but Article V of the Modified Brussels Treaty was, in any case, only ever credible via a recourse to NATO. Further, following the September 11th 2001 attacks on the US, NATO activated Article V for the first time in its history. In military terms this meant little as the US campaign in Afghanistan was a largely American affair conducted outside of NATO channels, but as a gesture of political solidarity it was highly symbolic and signalled a precedent for collective action should similar attacks occur against a European ally. ${ }^{32}$

Article V may remain firmly at the core of NATO, but the Alliance has also undertaken a conscious engagement in the changed meaning of security in Europe. The Strategic Concept of 1991 signified a conceptual move away from territorial defence as the central preoccupation of the Alliance. The successor document, the 1999 Strategic Concept, noted a commitment to 'a broad approach to security' and outlined a range of Alliance tasks over and above the more traditional ones associated with defence and deterrence. ${ }^{33}$ What is significant here is that an attempt at relevance has been maintained and that this has proved to be a motor to Alliance actions. The process of transformation that has resulted has reflected and indeed contributed to the growing complexity and diffusion in the governance of security in Europe.

In terms of heterarchy, NATO though it has remained the central provider of security in Europe, especially in the realm of military security, is not the sole provider nor does it claim to be. The assumption by NATO of certain functions of collective security, ${ }^{34}$ in particular new military missions or crisis management operations in the form of out-of-area peacekeeping and peace enforcement

31 See Stuart Croft, Jolyon Howorth, Terry Terriff and Mark Webber, 'NATO's Triple Challenge', International Affairs, 76:3 (2000), pp. 495-518.

32 Philip Gordon, 'NATO after 11 September', Survival, 43:4 (2001-2), p. 5.

33 The Alliance's Strategic Concept Approved by the Heads of State and Government Participating in the Meeting of the North Atlantic Council in Washington DC on 23 and 24 April 1999, NATO Press Release NAC-S(99)65, 24 April 1999. How dynamic this thinking has been is a moot point. The scant reference to terrorism in the 1999 Strategic Concept, for instance, suggests an organisational lag in the face of rising security threats.

34 David Yost, 'The New NATO and Collective Security', Survival, 40:2 (1998), pp. 135-60. 
operations, reflects the increasingly heterarchial nature of the governance of security in Europe. NATO's first step into this realm of collective security in 1992 was conditioned by the principle it would be willing to act out-of-area as a military crisis manager at the request of either the Conference on Security and Cooperation in Europe (now the Organization for Security and Cooperation in Europe - OSCE) or the United Nations. NATO had publicly recognised before 1992 that these two collective security organisations, among others, had an important role to play in ensuring security in the complex environment emerging in Europe. ${ }^{35}$ The Alliance stated unequivocally in its Rome Declaration in December 1991 that, ' $[\mathrm{t}] \mathrm{he}$ challenges we will face in this new Europe cannot be comprehensively addressed by one institution alone, but only in a framework of interlocking institutions tying together the countries of Europe and North America. Consequently, we are working toward a new European security architecture in which NATO, the CSCE, the European Community, the WEU and the Council of Europe complement each other.' ${ }^{36}$ These other institutions, however, lacked the military capabilities which were at times required for effective security management (the ongoing wars in the former Yugoslavia being a prominent case in point), and which the Atlantic Alliance could supply in a complementary role. The principle of acting at the request of the OSCE or the UN, it must be noted, was not upheld in the case of NATO's intervention in Kosovo. Alliance leaders argued at the time that the need to act overrode any preference to obtain authority from the UN given that Russia appeared bound to veto a Security Council resolution. Yet the authority of the UN proved enduring. Many NATO members were uncomfortable with the absence of an explicit mandate and the importance of the UN was swiftly resurrected. UNSCR 1244 of June 1999 furnished the formal framework for the conclusion of NATO's intervention and the consequent establishment of KFOR, the NATO-led (but UN mandated) peacekeeping presence.

Fragmentation of security authority in Europe was given further impetus by NATO through the development of the European Security and Defence Identity (ESDI) concept, which was designed not only to enhance the 'Europeanisation' of the Alliance itself but also to boost the ability of European states to act militarily without the US, first under the aegis of the Western European Union and then, after 1999, under the umbrella of the EU's European Security and Defence Policy (ESDP). NATO’s growing military relationship with the EU, though at times a cause of dispute amongst Alliance member states, has facilitated the promotion of an alternative source of military security in Europe. In line with this, NATO recently handed over to the EU responsibility for providing military security in Macedonia ${ }^{37}$

35 See, for example, 'Declaration on a Transformed North Atlantic Alliance issued by the Heads of State and Government Participating in the Meeting of the North Atlantic Council (The London Declaration)' London, 6 July 1990, paras. 21 and 22; <http://www.nato.int/docu/basictxt/b900706a. htm> (17/06/03); and 'The Alliance's Strategic Concept agreed by the Heads of State and Government Participating in the Meeting of the North Atlantic Council', Rome, 8 November 1991, para. 21; <http://www.nato.int/docu/basictxt/b911108a.htm> (17/06/03).

36 'Declaration on Peace and Cooperation issued by the Heads of State and Government Participating in the Meeting of the North Atlantic Council (including decisions leading to the creation of the North Atlantic Cooperation Council (NACC) (The Rome Declaration), Rome, 8 November 1991, para 3, <http://www.nato.int/docu/basictxt/b911108b.htm> (17/06/03).

37 See Judy Dempsey, 'EU launches military operation in Macedonia', FT.com, 31 March 2003, $<$ http://news.ft.com/servlet/ContentServer?pagename=FT.com/StoryFT/FullStory\&c=StoryFT\&cid= $1048313310793 \& p=1012571727166>(01 / 04 / 03)$. 
and the EU is actively interested in assuming from NATO responsibility for ensuring military security in Bosnia. ${ }^{38}$

The multiplication of security actors involved at all levels in the management of security affairs is an accompanying feature of the increased need for crisis management in Europe and the desire for greater Europeanisation. Since the mid-1990s, crisis management diplomacy in Europe has seldom been the sole responsibility of one institution, rather two or more institutions often work together cooperatively. In 2001 NATO and the EU worked in tandem at the diplomatic level to diffuse a brewing internal crisis in Macedonia, with each bringing different sets of possible pressures and incentives to the resolution of the crisis. But the burgeoning of security actors has been most evident in the provision of security on the ground. In the Balkans, NATO works not only with the EU, OSCE and the UN in post-conflict reconstruction efforts, but also with a range of public and private non-governmental actors ranging from the International Committee of the Red Cross to private contractors that are able to provide expertise and skills that NATO (or other institutions) cannot furnish. The war on terrorism has further added to this profusion of actors. ${ }^{39}$ Here cooperation includes a greater interaction in intelligence sharing with a range of national level intelligence officials and national ministry officials, national police forces, and corporate officials in the banking and investment sectors. Moreover, NATO's stated aim to support national governments in responding to biological and chemical disasters has opened up a requirement that it develop at least a minimal working relationship with a whole new set of public officials that are engaged in the field of disaster management.

At the institutional level, NATO very early pursued a political agenda to extend a hand of friendship to its former enemies and to develop a policy of political outreach to consult with them on security issues. ${ }^{40}$ The need to manage this policy of political outreach has resulted over time in the establishment within NATO itself of a set of interrelated formal bilateral and multilateral committees and meetings designed to manage security issues with non-member states. Central is the EuroAtlantic Partnership Council (EAPC), ${ }^{41}$ a multilateral forum in which NATO's 19 member states meet regularly with 27 partner countries 'to discuss political and security-related issues and develop cooperation in a wide range of areas'. ${ }^{42}$ The membership of the EAPC overlaps with a range of other institutional initiatives by NATO. One formal mechanism is the Partnership for Peace programme, which operates on a bilateral $(19+1)$ basis and is designed to facilitate security cooperation with each partner country, including on matters of defence planning and budgeting,

38 See Judy Dempsey, 'Bosnia role boosts EU military ambitions', FT.com, 25 February 2003, $<$ http://news.ft.com/servlet/ContentServer?pagename=FT.com/StoryFT/FullStory\&c=StoryFT\&cid= $1045511101057 \& p=1012571727166>(25 / 02 / 03)$.

39 For a statement of the Alliance's policy response to terrorism, see 'Prague Summit Declaration: Issued by the Heads of State and Government Participating in the Meeting of the North Atlantic Council in Prague on 21 November 2002' NATO Press Release 2002)127, 21 November 2002, para. $4 \mathrm{~d}$.

40 See 'The London Declaration'.

41 The EAPC replaced the North Atlantic Cooperation Council (NACC) in 1997.

42 'The Birth and Development of the EAPC Idea', NATO Handbook, <http://www.nato.int/pfp/eapc. htm> (15/06/03). 
military exercises and civil emergency operations. ${ }^{43}$ NATO has further established the NATO-Russia Council and the NATO-Ukraine Commission to provide regular forums for bilateral consultations in acknowledgment of the singular role these two countries have in European security. NATO has also sought to institutionalise its effort to develop mutual understanding with Algeria, Egypt, Israel, Jordan, Mauritania, Morocco and Tunisia through its Mediterranean Dialogue process, which includes bilateral meetings with each of these states (at 19+1) and multilateral meetings through its Mediterranean Cooperation Group (at 19+7). ${ }^{44}$ Underlying these formal forums NATO engages at the practical level in ongoing consultations with each of the partner states in meetings and activities that deal with common programmes in which these states participate with the Alliance. Much of this proliferation of formal and informal relations relate to security, and in particular military, matters, reflecting NATO's primary area of expertise, but these ties also extend to outreach projects on non-military related issues; for example, NATO's Science Committee runs projects with partner countries on matters such as the environment and other science and technological issues. ${ }^{45}$ NATO, in its effort to address a range of new issues and relationships has thus become an institutional structure within which a number of new formal bodies operate, informal dialogues and consultations relating to security occur, and formal and informal links with other regional institutions such as the EU, OSCE and UN have developed.

The ideational characteristic of governance has been central to the ongoing transformation of the Alliance. NATO emerged from the end of the Cold War period with a political agenda aimed at addressing a range of new security issues, in particular sources of instability in Central and Eastern Europe, but in spite of this forward-leaning intention Alliance rhetoric also seemed to imply that it remained first and foremost a collective defence organisation. In particular, NATO remained focused on the security of its territory and averse to operating militarily 'out of area'. In the first half of the 1990s this particular self-conception of its military role in European security increasingly came into conflict with the material reality of there being no obvious threatening external enemy and a growing argument that the Alliance had to address the ongoing horrors of the wars in the former Yugoslavia. The resulting debate pitched those member states who favoured a NATO still essentially geared to the familiar but less relevant tasks of static territorial defence against those who argued in favour of an Alliance 'in the service of shared values and common strategic interests' - a debate about whether the Alliance would go 'out of area or out of business'. ${ }^{46}$ The latter view prevailed and NATO emerged in rhetoric

43 'Partnership for Peace', NATO Handbook, <http://www.nato.int/pfp/pfp.htm> (15/06/03).

44 'Mediterranean Dialogue', NATO Handbook, <http://www.nato.int/med-dial/summary.htm> $(15 / 06 / 03)$.

45 For example, NATO's Virtual Silk Highway project, launched by the NATO Science Committee in 2002, is designed to improve the Internet connection of the academic communities of the Southern Caucasus and Central Asia so that they can communicate with colleagues on a global basis through a fast access to the web. See 'NATO Secretary General Inaugurates Virtual Silk Highway Project on Wednesday, 11 June 2003', NATO Press Release (2003) 063, 11 June 2003, <http://www.nato.int/docu/ $\mathrm{pr} / 2003 / \mathrm{p} 03-063 \mathrm{e} \cdot \mathrm{htm}>(16 / 06 / 03)$.

46 This phrase was coined by Senator Richard Lugar in a speech in June 1993. See. R. Asmus, Opening NATO's Door: How the Alliance Remade Itself for a New Era (New York: Columbia University Press, 2003), p. 33. 
and reality as an institution engaged in crisis management in locations outside of its traditionally defined area of operation. ${ }^{47}$

The most powerful transformational idea in the 1990s, however, has been that of enlargement. Enlargement was largely driven by the US, but the discourse surrounding it gained a dynamic that resulted in three new members being admitted in 1999 and then a further seven states being invited to join at the Prague Summit in November 2002. Beyond these, a number of other states, most notably Ukraine but also Georgia and Azerbaijan, have declared an interest in membership, while serious debates on possible membership have also occurred in the neutral states of Finland, Sweden and Austria. The hypothetical prospect of membership, however remote, for Russia has even been broached. ${ }^{48}$ The possibility of ongoing enlargement has raised a number of questions concerning a dilution of NATO's military effectiveness and an increased complexity of political decisionmaking. In spite of these concerns, enlargement has bolstered NATO's security primacy in Europe; not only does it extend the scope of Alliance commitment throughout the continent but it enhances its specifically European character. The US will remain primus inter pares but inevitably more European members will mean a consolidation of NATO more as a regional security organisation than as a trans-Atlantic one. ${ }^{49}$

NATO's continued adaptation through the 1990s and into the twenty-first century has been purposeful. NATO through the 1990s increasingly represented itself as an alliance of states joined together by common values of democracy, human rights and the rule of law. Indeed, in the 1990 London Declaration, NATO stated that it could, as 'an agent of change ... help build the structures of a more united continent, supporting security and stability with the strength of our shared faith in democracy, the rights of the individual, and the peaceful resolution of disputes. ${ }^{50}$ These and related liberal, capitalist values have served to furnish norms defining what constitutes acceptable behaviour for non-member states in both their internal and external activities, particularly if they aspire to become members. These values and norms are not simply political rhetoric, they are embedded in such official documents as the Membership Action Plan. ${ }^{51}$ These norms have served to socialise non-member states in the way that they approach and conduct their political and economic affairs, both internally and externally, thus creating a shared set of common principles and ideals across a range of states which serve as a foundation for an expanded zone of stability and security in Europe.

47 For a brief overview of NATO's initial reticence to act 'out of area' and the impact of the 'out of area or out of business' discourse, see Terry Terriff, 'US Ideas and Military Change in NATO, 1989-1994', in Theo Farrell and Terry Terriff (eds.), The Sources of Military Change: Culture, Politics, Technology (Boulder, CO: Lynne Rienner, 2002), esp. pp. 97-107.

48 Russian membership was given series consideration by the Clinton administration. See. Strobe Talbott, The Russia Hand: A Memoir of Presidential Diplomacy (New York: Random House, 2002), p. 131.

49 Anthony Forster and William Wallace, 'What is NATO For?', Survival, 43:4 (2001-2), p. 117.

50 'The London Declaration', para. 2.

51 See Membership Action Plan (MAP) NATO Press Release NAC-S(99) 66, 24 April 1999, $<$ http://www.nato.int/docu/pr/1999/p99-066e.htm> (15/06/03). 
In short, NATO has proven a durable and dynamic actor - a key agent in building security governance in Europe. Specifically, NATO's contribution can be seen in at least four ways. First, there is an institutional or regulatory component, in the shape of the organisational and military infrastructure of NATO itself coupled with the variety of arrangements linking NATO with non-members. Second, NATO has continued and, in some ways, has broadened its political purposes. The transAtlantic link remains fundamental (even if subject to periodic strain) as does the engineering of coordination and consensus on defence and security matters among a growing number of European states. Third, NATO has assumed an authority over a range of security-related issues. NATO may not be able satisfactorily to encompass responses to all of these (the terrorism issue, for instance), but on issues of peace-keeping, peace-enforcement, defence diplomacy, dialogue with partners (Russia, notably) and so on, it is of principal significance. Fourth, the Alliance has affirmed its position as an upholder of the ascendant set of values associated with security governance. As Frank Schimmelfennig has recently argued, NATO cannot simply be understood as a military alliance or the provider of shared security goods. It is equally 'an organisation [that represents] an international community of [liberal] values and norms.' 52 Those values may not be universally acceptable; or it may be argued that NATO has perverted them. ${ }^{53}$ However, the Alliance does at least claim them and, to some degree, act upon them; hence, the conditions of membership presented to aspirants and the claim to be acting upon values as much as interests in areas of intervention (most notably, the 'humanitarian war' over Kosovo). ${ }^{54}$

\section{Europeanisation}

The term 'Europeanisation' has been subject to two quite different uses. ${ }^{55}$ While some use the term to designate changes in domestic policy as a result of supranational developments, ${ }^{56}$ others have used the term to designate the extension of a policy field to the European level. ${ }^{57}$ Most mainstream literature prefers the expression European integration for this latter process. ${ }^{58}$ Thus, 'Europeanisation' has

52 Frank Schimmelfennig, 'NATO Enlargement: A Constructivist Explanation', Security Studies, 8:2/3 (1999), p. 213.

53 This was a criticism levelled against NATO's Operation Allied Force over Kosovo in 1999. See Noam Chomsky, The New Military Humanism (London: Pluto Press, 1999).

54 Adam Roberts, 'NATO’s "Humanitarian War" over Kosovo', Survival, 41:3 (1999), pp. 103-4.

55 T. A. Borzel and T. Risse, When Europe Hits Home: Europeanization and Domestic Change. European University Institute Working Paper, RSC no. 2000/56 (Badia Fiesolana: EUI 2000).

56 R. Ladrech, 'Europeanization of Domestic Politics and Insitutions: The Case of France', Journal of Common Market Studies. 32:1 (1994), pp. 69-88; C. Radaell, 'Whither Euopeanisation? Concept Stretching and Substantive Change', Paper presented at the Political Studies annual conference, 2000; and Vivien A Schmidt, The Futures of European Capitalism, (Oxford, Oxford University Press, 2002), esp. ch. 1.

57 S. S. Andersen and K. A. Eliassen (eds.), Making Policy in Europe: The Europeification of National Policymaking (London, New Delhi: Sage, 1993).

58 Jolyon Howorth, European Integration and Defence: the Ultimate Challenge? Chaillot Paper no. 43 (Paris, WEU, Institute for Security Studies, 2000) . 
increasingly come to acquire the former of the above two meanings. However, the impact of the European level on the national level is not the primary focus of this study. ${ }^{59}$ That said, the use of the term 'European integration' to categorise the processes we are analysing would also be quite inappropriate. Security and defence policy have been rigorously excluded from the supranational shifts proposed by the Convention on the Future of Europe. The use of the term 'Europeanisation' in this study is therefore rather different from either of the traditional usages. We have used it to explore the extent to which the European level is emerging as a necessary framework for the elaboration of security policy, without this necessarily implying integration as traditionally understood.

From the mid 1990s, a growing desire in Washington to shift the burden of security provision onto the Europeans while still allowing the US to exert a decisive influence, led to ESDI being developed within NATO. At one level, ESDI was essentially a technical-military arrangement aimed at allowing access to NATO/US assets by European Allies who would deploy them in operations to be conducted by the WEU. Although subject to considerable organisational efforts within NATO, ESDI proceeded slowly. Its greater significance, however, was political in that it signalled both a readiness on the part of the US to countenance a greater security role for the $\mathrm{EU}^{60}$ and determination on the part of the European Allies themselves to take greater responsibility for security management. By the mid 1990s, however, it was clear that ESDI offered little in the way of a distinct European security competence. If the Common Foreign and Security Policy (CFSP) launched at Maastricht was to be taken seriously it required significant, autonomous military and institutional capacity. Hence the leap forward following the Franco-British Saint Malo joint declaration on European defence in 1998 toward an ESDP housed within the EU. ${ }^{61}$

Innovations such as CFSP, ESDI and ESDP suggest a growing complexity and diffusion in the security governance of Europe. This complexity operates within the

59 For lengthy treatment of this theme, see Jolyon Howorth and Anand Menon (eds.), The European Union and National Defence Policy (London, Routledge 1997); Ben Tonra, The Europeanisation of National Foreign Policy: Dutch, Danish and Irish Foreign Policy in the European Union (London, Ashgate 2001).

60 The WEU had been referred to in the 1992 Maastricht Treaty as 'an integral part of the development of the [European] Union'. Thus, the development of an ESDI in which the WEU was the linchpin would, by extension, elevate the role of the EU.

61 The genesis of ESDP is detailed in Howorth, European Integration and Defence: The Ultimate Challenge?', pp. 9-30. ESDP is innovative in the development of a range of new political institutions, among them the High Representative - CFSP, the Political and Security Committee (PSC), the European Union Military Committee (EUMC) and the European Union Military Staff (EUMS). Jolyon Howorth, 'European Defence and the Changing Politics of the European Union: Hanging Together or Hanging Separately?', Journal of Common Market Studies, 39:4 (2001), pp. 765-89. It is innovative also in that it involves the EU developing for the first time a discrete military capacity, in the so-called 'Headline Goal' articulated at the Helsinki European Council in December 1999. This involves an ability 'to deploy within 60 days and sustain for at least one year military forces up to 50,000-60,000 persons capable of the full range of Petersberg tasks'. Presidency Conclusions, Helsinki European Council, <http://ue.eu.int/Newsroom/LoadDhttoc.asp?BID=76\&DID= $59750 \& \mathrm{LANG}=1>(5 / 9 / 02)$. The 'Petersberg Tasks' refer to humanitarian and rescue missions, peacekeeping and the use of combat forces for peace enforcement and derive from The Petersberg Declaration of the WEU of June 1992. They were subsequently incorporated into the Treaties of Amsterdam and Nice. 
EU itself. While there is no doubt that national governments, through the European Council, retain a tight control over policy outputs, the process of policy input and deliberation, negotiation and cooperation has become infinitely more subtle and, at the same time, more convoluted. This relates, specifically, to security governance in a number of ways.

Taking heterarchy or the existence of multiple centres of power first, one major feature of ESDP is its ambition for autonomy from NATO. Key documents refer to the EU's 'autonomous capacity to take decisions' and to 'launch and conduct EUled military operations' 'where NATO as a whole is not engaged'. ${ }^{2}$ However, the EU has devoted considerable energy to formalising relations with the Alliance on the assumption that recourse to NATO assets and capabilities would be required in the event of all but very small-scale EU-led operations. Further, there is limited support within the EU itself for the development of an ESDP that is truly autonomous of NATO and less still for the idea that ESDP be a step toward the 'common defence' of the Union noted at Maastricht and reiterated in the Treaties of Amsterdam and Nice. ESDP documentation is clear in noting that the policy 'does not imply the creation of a European army'63 and the Treaty of Nice in Article 17 affirms that the development of CFSP and ESDP should not prejudice the obligations of those member states who view NATO as their chosen instrument of defence. ${ }^{64}$ Yet notwithstanding the reality of the ongoing relationship between NATO and ESDP, most recently enshrined in the EU-NATO Declaration on ESDP (December 2002), there is no doubt that Europeanisation of security governance has brought into the equation several new (and growing) power centres which did not exist at the time of the Cold War: the European Council, the ESDP institutional nexus (see below), and, eventually, a credible military force which, while not equating to a European army, will nevertheless emerge as a power to be reckoned with.

Multiple actors are a second feature of Europeanisation. Formerly, defence policy was decided - hierarchically - first in NATO, then interpreted by member state governments, and finally implemented by defence ministries. Today, the picture is very different. Quite apart from institutional multiplication involvng the EU, the process of delivering security involves many actors whose inputs were previously negligible or non-existent. Post-conflict reconstruction - in the Balkans, in Afghanistan and in Iraq - calls directly on the skills and resources of many private and non-governmental actors from economic investors to judges, from construction companies to policemen, from medical charities to administrators. The 'war on terrorism' has also brought forth an unparalleled involvement in the delivery of security by intelligence officers and networks, Interior Ministry officials, bankers and investment brokers, police forces and other experts and agencies. The profusion of think-tanks and specialist journals focusing on security issues, the unparalleled attention paid to security by the media and the generation of policy options from outside government are all factors which security decision-makers can ill afford to ignore. Finally, where defence industries formerly confined their role to that of accepting procurement orders from governments and (eventually) delivering the

\footnotetext{
62 Introduction to 'Presidency Report on the European Security and Defence Policy', Annex VI to Presidency Conclusions, Nice European Council (7-9 December 2000).

63 Presidency Conclusions, Helsinki European Council (10-11 December 1999).

$64<$ http://www.europa.eu.int/eur-lex/en/treaties/dat/nice_treaty_en.pdf> (5/9/02).
} 
goods, today's mega-companies function primarily in a global market-place and have forced governments to act like customers. ${ }^{65}$ They have become, in short, essential actors in the security governance process.

At the institutional level, the proliferation of committees and meetings - unilateral, bilateral and multilateral - has led to a great deal of duplication and to a considerable increase in the overall volume of work. More significantly, it has led to new tensions between national capitals and centralising tendencies in Brussels. The latter comes in two forms. First, as four separate clusters of Brussels-based permanent representatives (the Committee of Permanent Representatives [Coreper], the PSC, the Policy Unit attached to the High Representative - CFSP and the EUMS) get to know one another and 'consociationalise', it is hard to imagine that they will not assume a greater and greater tendency to develop a collective ethos of their own and to generate transEuropean perspectives on CFSP and ESDP. While this need not automatically lead to tensions with the national capitals, it is almost certain to lead to a relative strengthening of their roles and a possible corollary weakening of the formerly unchallenged influence of Foreign Ministries. ${ }^{66}$ Second, the role of the European Commission is assuming ever-greater importance, particularly in the field of civilian crisis management, and it is the Commission which is largely responsible for the implementation of ESDP/CFSP decisions and the management of the CFSP budget. New institutional actors are being called into existence through the Convention process - a permanent President of the Council, an EU Secretary of State, an enhanced Commission President - all of whom will add to the institutional complexity of ESDP and to the consolidation of governance practices.

Turning to the ideational issue, Europeanisation does not necessarily suggest a complete harmony of European views. The EU includes nations such as Denmark (which rejects outright the very principle of an autonomous EU military capacity), France (which would like EU capacity to rival that of the US), the UK (which has a centuries-old tradition of muscular intervention), Sweden (which has for long emphasised conflict prevention and civilian peace-keeping), Greece (which has potentially serious security problems on its borders) and Luxembourg (which has no armed force worthy of the name). This differentiation is likely to become even more pronounced once the EU enlarges from its current fifteen member states to twentyfive after 2003. However, by the same token, the role of ideas and discourse, of epistemic communities, in overcoming these national policy legacies has been and will continue to be fundamental. The Saint-Malo 'breakthrough' was largely the result of ideational interactions between a handful of key officials in Paris and London who, in tussling with the problems of making WEU work, eventually generated an alternative idea - ESDP - which led to the shelving of WEU and the promotion of the EU as a new locus for the delivery of European security. ${ }^{67}$ The gradual emergence of a coherent European security culture, already perceptible

65 See B. Schmitt (ed.), Between Cooperation and Competition: the Transatlantic Defence Market, Chaillot Paper no. 44 (Paris: Institute for Security Studies, Western European Union, 2001).

66 Howorth has called this process 'supranational intergovernmentalism'. See European Integration and Defence: the Ultimate Challenge?, p. 36.

67 Jolyon Howorth, 'Ideas and Discourse in the Construction of a European Security and Defence Policy', to be published in a special 2004 edition of West European Politics on 'Europeanisation, Policy Change and Discourse', edited by Vivien Schmidt and Claudio Radaelli. 
through the fog of national traditions, ${ }^{68}$ will be the great challenge of the coming decades.

What all of this suggests is that the ideational significance of Europeanisation resides in the fact that it is a process underpinned by conceptions, expressly articulated within a European institutional context, of an appropriate security order - one shared on both sides of the Atlantic. In many ways this has been a running theme throughout the entire postwar history of European integration. As Laffan et al. have argued, from its very inception in the 1950s, integration 'was about security as much as it was about economic integration [...] Since then, a major feature of the EC's and then the EU's role has been the stabilisation of western Europe and - increasingly - of the "near abroad" in the wider Europe, the Mediterranean and elsewhere. ${ }^{69}$ The EU, indeed, has achieved considerable success in this regard. In Western Europe, at least, it has made a fundamental contribution to the creation of a Deutschian 'pluralistic security community'. Since the end of the Cold War, the EU (with American support) has embarked upon a course that is aimed at consolidating this order ('deepening') while at the same time extending it ('widening'). This is a process that has been far from straightforward, and also at times hesitant, ill-articulated and controversial among the member states. ${ }^{70}$ Yet, in rather grand terms, two of the Union's major projects, those of monetary union and enlargement, fall within it. As for the particulars of the EU's external role, here the record of the 1990s was mixed. However, the hesitant but inexorable progress of CFSP was significant in that it meant the development of conflict prevention as a central feature of the EU's external purpose. ${ }^{71}$ Adding modest military instruments to this civilian capability has been a central rationale of ESDP. ${ }^{72}$

Thus, we discern the purposeful construction of a European framework for the delivery of regional security. Security governance in the EU has been the result of a growing awareness not only of the inadequacy of national solutions, but also of the increasing limitations, in a changing post-Cold War world, of traditional Alliance policies. Few NATO member states relish the prospect of transferring responsibility for security and defence (ultimately the first and last bastions of sovereignty) to a collective European entity. And yet, the history of European security initiatives over the last fifty years (from the European Defence Community to ESDP) has witnessed

68 Jolyon Howorth, 'The CESDP and the Forging of a European Security Culture', Politique Européenne, vol. 8, Autumn 2002, pp. 88-108.

69 Brigid Laffan, Rory O'Donnell and Michael Smith, Europe's Experimental Union: Rethinking Integration (London and New York: Routledge, 2000), pp. 38-9.

70 The notion of a security order is implicit in a good deal of EU documentation, although rarely spelled out at length and in detail. For an example see European Commission, External Relations Directorate General, CARDS Assistance Programme to the Western Balkans, Regional Strategy Paper, 2002-2006, <http://europa.eu.int/comm/external_relations/see/docs/cards/sp02_06.pdf> (24/8/02). Expositions on this theme are also apparent in some of the interventions of the High Representative - CFSP, Javier Solana and the EU Commissioner for External Affairs, Chris Patten. See, for instance, Javier Solana, 'Europe: Security in the Twenty-First Century' (The Olaf Palme Memorial Lecture, 20 June 2001), <http://ue.eu.int/solana/print.asp?docID=66960\&BID=107> (24/8/02) and Chris Patten, 'A Voice for Europe? (The Brian Lenihan Memorial Lecture, Dublin, 7 March 2001), $<$ http://europa.eu.int/comm/external_relations/news/patten/speech01_111.htm> (24/8/02).

71 Christopher Hill, 'The EU's Capacity for Conflict Prevention', European Foreign Affairs Review, 6:3 (2001), pp. 315-33.

72 See Javier Solana, 'The CFSP in an Enlarged Union' (speech to the Institut français des relations internationales, 1 March 2001). 
the gradual articulation of a common approach. The involvement in this process of heterarchical power centres, multiple actors, new institutions and ideational exchanges has generated a powerful and purposeful momentum in favour of ESDP a process which saw France and Britain, at the Le Touquet summit in February 2003, moving resolutely ahead even as their representatives in the United Nations were at loggerheads over US policy towards Iraq. The Europeanisation of security has been the great political revolution of the late twentieth and early twenty-first centuries.

\section{Inclusion and exclusion in European security governance}

During the Cold War the security of Europe was bipolar and organised around mutually exclusive spheres of influence. By contrast, the context of security governance after the Cold War has been increasingly determined by the continental spread of the formerly 'western' sphere organised around the EU and NATO. Alternatives in the shape of neutrality, pan-European structures such as the OSCE or sub-regional groupings like the Russian-led Commonwealth of Independent States (CIS) and the GUUAM (Georgia, Ukraine, Uzbekistan, Azerbaijan and Moldova) grouping have proven tenuous and lacking in credibility. ${ }^{73}$ The one alternative that might have mattered is that of American power, but in Europe at least US policy has been fashioned through NATO - indeed, Europe appears to be one region where American unilateralist impulses have been effectively restrained by multilateral necessity.

The absence of alternatives does not, however, rule out a politics of exclusion. The enlargement of NATO and the EU, as well as various procedures of association and partnership with these bodies, has opened up the possibility of pan-European integration, ${ }^{74}$ but as this inclusive prospect has unfolded it has brought with it, paradoxically, exclusionary consequences. This has been apparent in four senses: first, among those states who wish to enter enlarging organisations but are denied membership (Turkey and Ukraine, for instance); second, among those states (most notably, Russia) who eschew such an aspiration but who, as a consequence, perceive themselves as marginalised and as having their status undermined; third, among states (for example, the Federal Republic of Yugoslavia [FRY] under Milosevic) who have actively opposed the dominant organisations; and fourth, among 'forgotten countries' (such as Moldova and Belarus) outside the pale of enlargement and cast adrift politically and economically. ${ }^{75}$

In one sense, it should come as no surprise that themes of inclusion and exclusion have loomed large amidst Europe's political reconfiguration. By definition, any form

73 Dimitri Trenin, 'Introduction: the Grand Redesign', in A. Lieven and D. Trenin (eds.), Ambivalent Neighbours: The EU, NATO and the Price of Membership (Washington, DC: Carnegie Endowment for International Peace, 2003), p. 11.

74 Helen Wallace, 'Pan-European Integration: A Real or Imagined Community?', Government and Opposition, 32:2 (1997), pp. 215-33.

75 John Löwenhardt, Ronald Hill and Margot Light, 'A Wider Europe: the View from Minsk and Chisenau', International Affairs, 77:3 (2001), pp. 605-20. 
of political life rests upon some specification of what constitutes its component parts and thus who or what is included or excluded. ${ }^{76}$ Thus, domestic politics usually refers to citizens and subjects (of a state), or members (of a club, party, association and so on) ${ }^{77}$ International politics, meanwhile, even when conceived of as principally the realm of states, often sees states as conjoined or divided by differing degrees of formal participation in joint endeavours. Yet how does this square with governance? A governance perspective, after all, is one premised implicitly on inclusion given its emphasis on a plurality of actors and multiple centres of power. Inclusiveness is apparent in the construction of decisions through the accommodation of interests and a search for consensus, through implementation that involves delivery by a wide range of affected actors, and through the sanctions of a number of institutions and regimes to enforce compliance when necessary. ${ }^{78}$ Governance when applied to domestic settings does not assume, however, that inclusiveness is comprehensive or equitable among actors. ${ }^{79}$ The same applies in international life. What is crucial, however, is that the legitimacy and rationale of governance rests on inclusivity; thus, while exclusion may be unavoidable in some senses, it is a phenomenon which systems of governance seek to ameliorate rather than simply tolerate. Governance does not eradicate exclusion, but it does involve processes for managing it.

Governance as noted above rests on an assumption of heterarchy and multiple centres of power. Power in post-Cold War Europe is not, however, competitively wielded as was the case with Cold War bipolarity. Rather than organising itself as a system against a rival centre of power, security governance involves the incorporation of potential rivals. At one level, this was a method employed among EuroAtlantic states during the Cold War itself. Vanquished centres of power (Germany), those in the ascendant (the US) and those on the wane (the UK and France) jointly managed their common security and in the process jettisoned historical animosities as well as maintaining the institutional edifices of west European stability, the EU and NATO. Amidst the anguished debates over Iraq and the fractures within the EU that surrounded negotiations over the Treaty of Nice and the European Convention, it would be easy to overlook the fact that the EU and NATO have continued to play this important function. In post-Cold War Europe, furthermore, the method has been extended to post-communist and post-neutral Europe. Most significantly, what had been a rival bloc - the Warsaw Pact - has disappeared, and consequent upon enlargement the majority of its former members will have been absorbed into the EU and NATO by 2004.

The important exception to this trend remains Russia. While prostrate as a great power, Russia has retained an ability to affect the security of its neighbours. In some cases (Moldova, Belarus, Armenia and, to a lesser degree, Ukraine) this has meant the maintenance of dependent relations, while in others (Georgia) it has amounted to

76 Andrew Linklater, The Transformation of Political Community (Cambridge: Polity Press, 1998), pp. 113-15.

77 Michael Walzer, Spheres of Justice: A Defence of Pluralism and Equality (Oxford: Basil Blackwell, 1983), pp. 31-63.

78 The Commission on Global Governance, Our Global Neighbourhood, pp. 2-3; Rhodes, 'The New Governance', p. 657; Jan Kooiman, 'Social-Political Governance: Introduction', in Jan Kooiman (ed.), Modern Governance: New Government-Society Interactions (London: Sage, 1993), pp. 1-6.

79 Pierre and Peters, Governance, Politics and the State, pp. 14-27. 
active destabilisation. Further, the Russian leadership under both Boris Yeltsin and Vladimir Putin has continued to harbour grandiose ambitions, 'an end-vision of Russia's place in the world' that goes beyond the country becoming just a regional power akin to the UK, Germany or France. ${ }^{80}$ Add to this geographic enormity, undoubted material potential and fragile democratisation, then Russia could well be set apart from the main dynamic of security governance in Europe. Should it recover economically and achieve lasting political stability, Russia's status as a rival could well follow. Yet this is not the only possible outcome. Increasing economic interdependence, the Russian elite's increasing anxiety at the perceived challenges posed by terrorism, criminality and Islamic fundamentalism to the south, as well as the limitations of the Eurasian alternative premised on alliances within the CIS or with China, all suggest that Europe is the 'natural place for Russia's own integration' ${ }^{81}$ The record of Russian interaction in matters of European security, further, has been one of ever-increasing cooperation at a practical level and resignation rather than active opposition to initiatives (such as NATO enlargement and enforcement in the Balkans) with which it has disagreed. This may at times have been premised on pragmatic realism rather than conviction, but in the post-Soviet period, a cooperative and generally Eurocentric orientation has become established as arguably the main tendency of Russian foreign policy. ${ }^{82}$

The effort by NATO and the EU to manage and coordinate relations with Russia, Ukraine and other states has been a basis for the multiplication of institutional actors as discussed above. Russia's engagement with Europe has occurred as a statelevel process (the Moscow-Paris-Berlin triangle, for instance), but this has been far less substantive than Russia's interaction with institutional actors. Deliberate and considered institutionalisation has significantly contributed to the success of Russia's incorporation, indeed, the multiplicity of actors with which it has been faced has blunted what might otherwise have been a much more singular and competitive relationship.

With respect to institutionalisation, Moscow has been coupled to security governance in Europe by a number of specially-tailored arrangements: the NATO-Russia Permanent Joint Council (and its replacement the NATO-Russia Council), separate chains of command for its peacekeeping forces in Bosnia and Kosovo and a panoply of initiatives with the EU up to and including annual summit-level meetings, as well as particular provisions on ESDP, counter-terrorism, and non-proliferation and disarmament. These have, on the one hand, pandered to its great-power aspirations while, on the other, have facilitated enough substantive cooperation to be of more than simply symbolic significance. Moscow, it is true, has often resented the fact that it has had to ingratiate itself with the EU and NATO, two organisations not of its making, but the long-term effect has been to offer it a channel of involvement with the core bodies of security governance that has mitigated the sense of exclusion in Moscow and reinforced the European perspective of its leadership.

80 B. Lo, Vladimir Putin and the Evolution of Russian Foreign Policy (London: the Royal Institute of International Affairs/Blackwell Publishing, 2003), p. 111.

81 Dimitri. Trenin, The End of Eurasia: Russia on the Border between Geopolitics and Globalisation (Washington DC: Carnegie Endowment for International Peace, 2002), p. 328.

82 Vladimir Baranovsky, 'Russia: A Part of Europe or Apart from Europe?', International Affairs, 76:3 (2000), pp. 451. 
Beyond Russia, the dynamic of institutionalisation has been equally significant. Enlargement first and foremost has extended institutionalised cooperation across the continent. By May 2004 NATO will consist of 26 members and the EU 25, 19 of which will be in common. As Antonio Missiroli has pointed out, '[t]aken together the two organisations will cover almost all of continental Europe and represent a majority within the OSCE'. ${ }^{83}$ Given the distinct possibility of Bulgarian and Romanian entry into the EU in 2007 and the not improbable accessions of Albania, Croatia and Macedonia into NATO at around the same time then the process of continental integration and transnational governance will have been extended still further. This, moreover, only caps a process of incorporation already well in train. Since the mid 1990s both the EU and NATO have exerted a telling effect upon aspirant states through the articulation of accession conditions, something that has amounted de facto to an extension of governance beyond the specific geographic area constituted by their formal memberships. ${ }^{84}$

Of course, enlargement does produce tensions. To be in the EU, for instance, confers upon member state populations, freedom of movement and freedom to work within the Union, legal protection provided by the European Court of Justice and expectations of stable economic growth and integration. To be outside is to be denied these benefits. ${ }^{85}$ The border which marks out those who enjoy the benefits of membership from those who do not may in some senses be 'soft' (it is permeated by migration, both legal and unregulated, as well as by transnational criminal activities) but it has a 'hard' character also in the shape of the Schengen border regime - a regime the new entrants are expected to enforce upon entry to the Union. For states such as Russia and Ukraine who find themselves on the wrong side following enlargement this is perceived as a very real source of exclusion and one, moreover, that has overt security as well as societal implications. ${ }^{86}$

Further, the belated but ultimately expansive growth of NATO and the EU has, in many respects, been demand-led. It has been driven by the aspirations of the candidates based on a powerful mix of identity factors (the fabled 'return to Europe'), security predicaments (insurance against regional destabilisation as in the former Yugoslavia and ensuring distance from Russia) and, in the case of NATO, getting as close as possible to the US. Yet as enlargement has proceeded, to be left out of the process appears increasingly anomalous, the source of a sense of insecurity and potential abandonment. For Albania, Macedonia and Croatia the desire to join NATO has been made that much more urgent by the failure to receive formal invitations at NATO's Prague summit. A similar point can be made regarding Turkey's spurned aspirations regarding the EU. Even greater is the sense of exclusion felt in Georgia and among Eurocentric elites in Ukraine - where real but

83 'Two Enlargements and a Devolution', Newsletter no.5, EU Institute for Security Studies, January 2003, p. 3.

84 Friis and Murphy, 'The European Union and Central and Eastern Europe', pp. 211-32; Schimmelfennig, 'NATO Enlargement', pp. 198-234.

85 N. Winn, 'In Search of Europe's Internal and External Borders: Politics, Security, Identity and the European Union', Perspectives on European Politics and Society, 1:1 (2000), p. 29.

86 The status of the heavily militarised Russian exclave of Kaliningrad has been a thorn in the side of Russian-EU relations in view of the upcoming accession to the Union of its two bordering states, Poland and Lithuania. 
probably unrealisable aspirations for NATO and EU membership have developed, in part as a means of countering overweening Russian influence.

Exclusion, however, is not total. What is significant about security governance is the development of forms of institutional cooperation which blur the formal distinction between those who are and those who are not members of its core organisations. Initiatives emanating from NATO provide coverage of the entire Eurasian landmass. This is true of the EAPC and its 27 members that are incorporated within the PFP programme, a large number of whom have partaken in Alliance-led peacekeeping in Bosnia, Kosovo and Macedonia, an initiative which in its own right has meant the establishment of de facto NATO protectorates in the Balkans. The EU, similarly, has gone to great lengths to fashion forms of association with non-members over ESDP. ${ }^{87}$

The ideational basis of security governance also demonstrates a tendency towards inclusivity, albeit again one accompanied by certain tensions. One manifestation of this is the meaning that has been attached to 'Europeaness' after the Cold War. At one level, this has a seemingly straightforward geographic application for NATO and EU enlargement have been premised on the geographic (that is, European) credentials of membership candidates. This was also the case during the Cold War, but the stricture was meaningless in the context of East-West division. NATO and the EU, indeed Western Europe in general, were defined in juxtaposition to the 'other Europe' that was both spatially and, to some degree, culturally separate. ${ }^{88}$ This separateness was modified in its essentials with the Cold War's demise. Both Article X of NATO's Washington Treaty and Article 237 of the Treaty of Rome had stipulated that membership of the Alliance and of the EU be open to any European state, and in consequence the political leaderships of many postcommunist states have gone to considerable lengths to emphasise their European location. This claim to inclusion has been relatively straightforward for some - the Poles, the Hungarians and the Czechs, for instance, have a valid geographic claim to be at the centre of Europe. For others, it has been a much more troubling matter. While none would dispute that the former Soviet Central Asian states are outside of Europe (although even this has not precluded their membership of the OSCE), the status of the Transcaucasian states of Armenia, Azerbaijan and Georgia as well as of Turkey is much less clear-cut. Reflecting these uncertainties, neither the EU or NATO has been able to offer a succinct definition of what constitutes the region of Europe and thus where the geographic boundaries of their dual processes of enlargement lie.

Of course, 'Europeaness' is not simply a matter of geography; the meaning of Europe is also a matter of purposeful construction. The EU, in particular, has done much to stress the notion of European values and these tend to equate with its conditions of membership. While less explicitly European (given the predilections of the Americans), the conditions of NATO entry have been similar. The values of economic liberalisation, democracy, the rule of law, the professionalisation of

87 These arrangements are covered in detail in Mark Webber, Terry Terriff, Jolyon Howorth and Stuart Croft, 'The Common European Security and Defence Policy and the "Third-Country" Issue', European Security, 11:3 (2002), pp. 75-100.

88 J. Hagen, 'Redrawing the Imagined Map of Europe: the Rise and Fall of the "Centre", Political Geography, 22 (2003), p. 492. 
government bureaucracies and civilian oversight of the armed forces constitute the basis upon which new and candidate states of the EU and NATO have been incorporated into these two crucial organisations of security governance. The emphasis on these values and the practical processes of conditionality and socialisation which have followed has fundamentally transformed domestic governance in a number of post-communist states ${ }^{89}$ as well as laying the ideational basis for inclusion in the broader international processes of security governance. In so doing, however, it leaves certain states in its wake. What matters in this regard is not necessarily inadequacies in matching up to the 'Westernistic' community of norms, but rather to be seen to be actively opposing them. There is a world of difference between, on the one hand, Bulgaria, Romania or Albania, states which are formally committed through process of accession and consequent security cooperation to these norms, and, on the other, states which openly flout them both in their domestic practices and foreign policies - states such as Serbia under Milosevic, Belarus under Aleksandr Lukashenko or, even at times, Ukraine under Leonid Kuchma. Only Russia seems to have escaped censure in this regard (despite its departure from European norms in Chechnya) a level of toleration that reflects the necessity of accommodation noted above.

The foregoing demonstrates that security governance does have an inclusive basis in Europe even if this is not entirely comprehensive or equal. Inclusion has occurred not through the elaboration of institutions and norms that reflect some new expanded sense of European community created ab initio after the Cold War. Rather, it has been premised on previously excluded states joining (or, in some cases, finding accommodation with) a pre-existing community still anchored in western Europe and north America, the institutions and norms of which have underpinned a system of security governance with claims to pan-European relevance. Insofar as this is a system with purpose, it is a purpose that has been defined by its western origins, the manner in which the system's two institutional offspring (NATO and the EU) have interacted and, within this context, how the Western powers have aggregated their preferences. The security orientations of NATO and the EU covered in the previous sections have dominated discourse and practice in Europe. In some instances, these have not been discordant with those outside these organisations. The effort at promoting stability in the Balkans, albeit ineffective for long periods and problematic in all manner of respects, cannot be entirely separated from the concerns of established governments in Bosnia, Macedonia or Albania. In other cases, however, this discourse and the actions it gives rise to are in contradiction with the preferences of non-members and this is a tension that has some very practical repercussions. First, in terms of how governance structures manage relations with the 'excluded'. This has been sometimes through a policing function (as in the case of deviant states such as, formerly, the FRY) and at other times attempted accommodation on terms acceptable to the 'included' (as in the case of potential system destabilisers such as Russia or, in the particular case of ESDP, special provisions geared towards Turkey).

The second repercussion concerns how the excluded frame their own foreign and domestic policies in a regional setting seemingly not of their own making. Exactly

89 See A.C. Janos, 'From Eastern Empire to Western Hegemony: East Central Europe under Two International Regimes', East European Politics and Societies, 15:2 (2001), pp. 221-49. 
what course this takes depends upon the extent of exclusion and where the state stands with regard to the underlying norms which security governance aspires to uphold. Should it, in other words, pursue a foreign policy (and indeed, promote a domestic political and economic order) consistent with a higher degree of inclusion or should it, rather, seek to revise that system and lay down its own terms for incorporation? ${ }^{90}$

\section{Conclusion}

Our view of security governance in post-Cold War Europe has been premised on three assumptions. First, that the meaning of 'security' has changed both conceptually and in policy terms. Second, that there is a need to identify the manner of this change and its underlying dynamics. And third, that states and the international organisations through which they act remain the dominant actors of security; two in particular are key in this regard - NATO, first and foremost, and the EU to a lesser extent. These assumptions, in turn, have led us to suggest that Europe is characterised by heterarchy, or multiple centres of power, a multiplication of actors involved in the provision of security, and highly developed forms of institutionalisation and community building, with these forms being extended across the continent, functionally within the sphere of security and geographically through enlargement and partnership. These processes are, in turn, accompanied by an ideational discourse (apparent not least over the issue of Europeanisation) and a dynamic relationship between inclusion and exclusion.

This article has demonstrated that a governance perspective offers a useful framework for understanding and conceptualising these developments. Pierre and Peters have noted that governance approaches exhibit a tension 'between governance as phenomenon and governance as theory or analytical framework' ${ }^{91}$ Our claim, nonetheless, is that governance in the context of European security is useful on both counts; it is a framework that describes and elucidates some of the core features of the actuality of Europe's security relations.

The dynamism of the concept lies in its ability to apprehend some of the key questions of post-Cold War security management. Why has the institutionalisation of security placed a premium on NATO (an organisation which endures despite persistent claims of its demise) and also on the EU (an organisation whose security functions once only implicit have become increasingly overt)? While not fully developed, security governance offers an explanation that is alert to functionalist explanations associated with institutionalism, power-based perspectives which consider state preferences, and ideational (or constructivist) considerations which allow for norms as driving influences. Of course, this opens the concept up to charges of theoretical sloppiness and a more extended formulation would require its synthetic qualities to be more rigorously articulated. Yet tentatively perhaps, governance provides a framework of analysis that can ascertain how the 'rules' of security

\footnotetext{
90 This, of course, is a dilemma particularly acute in Russia.
}

91 Pierre and Peters, Governance, Politics and the State, p. 24. 
develop - insofar as it focuses on how such rules are imprinted within institutions (both in their normative claims and their policy actions), institutions which then act as vehicles for extending and entrenching such rules beyond what had been their core areas of functional and geographic competence. Similarly, governance is a lens that can help understand how security is produced. Its focus on states, organisations and norms allows for a multifaceted approach to the interpretation of threat. The post-' $9 / 11$ ' emphasis on terrorism, for instance, is not just the consequence of the increased prominence of a new challenge 'out there in the real world' (although this material reality is part of it). What matters is how this threat has been interpreted and acted upon. Terrorism is a particularly noteworthy case because it is a challenge both to the traditional prerogatives of the state (the protection of citizens from external danger), is contrary to the norms of the liberal democratic community and is an affront to the efficacy of organisations such as the EU and NATO whose claim to be the providers of security can no longer be judged (as it was during the Cold War) by reference to an armed mirror-image of themselves. 